\title{
Size matters for risk assessment and resource allocation in bivalves
}

\author{
Keith D. Johnson, Delbert L. Smee* \\ Department of Life Sciences, Texas A\&M University-Corpus Christi, 6300 Ocean Dr., Corpus Christi, Texas 78411, USA
}

\begin{abstract}
Nonlethal predator effects can significantly influence trophic interactions, and in this study we examined how size relationships between predators and prey would influence the expression of nonlethal predator effects. We assessed how size and vulnerability to predators would influence nonlethal effects in bivalve species common to oyster reefs. We used 2 size classes of mussels Ischadium recurvum, clams Mercenaria mercenaria, and oysters Crassostrea virginica as prey and compared energy allocation and growth of small vs. large bivalves in the presence of Atlantic mud crabs Panopeus herbstii, a common, resident reef predator. After a $45 \mathrm{~d}$ field experiment, we observed significant differences in growth among bivalves in response to mud crabs, but the effects were size and species dependent. In the presence of mud crabs, small clams and small oysters grew significantly less soft-tissue, small mussels grew more shell mass, large clams grew less shell mass, and large mussels grew less tissue and shell mass. Significant differences in the growth of larger oysters were not found. Changes in growth reflect resource allocation differences in response to predators and most likely resulted from costs associated with feeding reductions to minimize release of metabolites attractive to predators and/or allocation of additional energy for morphological defense to minimize predation risk. Fecundity is positively correlated with size in bivalves, and the ability to detect predation risk and appropriately allocate resources may be important for future reproductive output of these species. Smaller bivalves were more vulnerable to mud crab predators in laboratory feeding assays. Since size is inversely related to bivalve susceptibility to mud crabs predation, slower growth may lengthen the time that these bivalves are vulnerable to mud crabs and therefore increase their mortality. Results from this study suggest that mud crabs can affect the growth and fecundity of commercially important bivalves by nonlethal interactions and that size is an important consideration when investigating the propagation of nonlethal predator effects.
\end{abstract}

KEY WORDS: Clam · Crab · Crassostrea virginica - Inducible defense - Mercenaria $\cdot$ Mussel · Non-lethal predator effect · Oyster · Panopeus

\section{INTRODUCTION}

Avoiding predators is often necessary for prey survival, but predator avoidance is costly as it requires that prey allocate resources to defense rather than growth or reproduction (Lively 1986, Harvell 1990, Kats \& Dill 1998, Schoeppner \& Relyea 2005, Hay 2009). For example, predator-induced behavioral changes such as a reduction in prey foraging time (Turner 2004, Large \& Smee 2010) or feeding cessa- tion (Smee \& Weissburg 2006, Naddafi et al. 2007) can minimize predation risk, but may ultimately lower growth and fecundity (Relyea 2001, 2002, Fassler \& Kaiser 2008, Bourdeau 2010). Constant exposure to risk may also decrease body size and increase the likelihood of being consumed (Edeline et al. 2010). To minimize costs associated with predator avoidance, many prey species use plastic responses to predation risk and change their morphology, behavior, or life history only when situations 
pose risk of injury or death (Lively 1986, Crowl \& Covich 1990, Harvell 1990, Kats \& Dill 1998).

Prey often use chemical cues to evaluate predation risk that emanate from predators, injured conspecific or heterospecifics, or some combination thereof (Kats \& Dill 1998, Hay 2009, Ferrari et al. 2010). Yet, for these to be cost-effective, prey need to be able to evaluate differences in chemical cues between predators, to distinguish the level of risk associated with individual predators (based on predator characteristics such as relative predator size or predator type) and to respond appropriately. Surprisingly, few studies have examined how predator size or biomass influences the propagation of nonlethal effects on prey populations (but see Schoeppner \& Relyea 2008, Toscano \& Griffen 2012, J. M. Hill \& M. J. Weissburg unpubl.). Similarly, it is well established that prey size influences risk of being consumed (Micheli 1995, Wong et al. 2010), but few studies have examined whether prey size influences reactions to predation risk (but see Nakaoka 2000).

Bivalves have routinely been used in studies of phenotypic plasticity, and have been shown to produce thicker shells after exposure to predator exudates (Leonard et al. 1999, Nakaoka 2000, Smith \& Jennings 2000, Caro \& Castilla 2004, Cheung et al. 2004). In addition to increasing shell thickness in the presence of crushing predators (crabs), mussels (Mytilus edulis) also increased byssal thread production to increase the force needed by predators to remove them from hard substrates (Cote 1995, Leonard et al. 1999, Shin et al. 2009) and to increase abductor muscle mass for some predators (whelks) (Freeman 2007, Freeman et al. 2009). Hard clams Mercenaria mercenaria grow more slowly in the presence of knobbed whelk Busycon carica predators (Nakaoka 2000), possibly because they reduce their feeding (pumping) time in response to them (Irlandi \& Peterson 1991, Smee \& Weissburg 2006). Changes in morphology, such as increased shell thickness, are a trade-off with soft tissue mass and gonad size. In bivalves, there is a positive relationship between mass of soft-tissue (including gonads) and fecundity, and a negative relationship between shell thickness and soft-tissue mass (Peterson 1986).

Although numerous studies have examined phenotypic plasticity in mussels, to date only laboratory studies have examined plastic responses of Eastern oysters Crassostrea virginica to predators (Newell et al. 2007, Lord \& Whitlatch 2012). Oysters are an important foundation species in estuaries along the Gulf and East Coasts of the U.S., and they provide many ecosystem services (Grabowski \& Peterson
2007). Since oysters are an important foundation species, the potential for predators to induce changes in oyster growth and cause reductions in oyster fecundity may potentially have important consequences for oyster populations and estuarine systems by reducing future oyster populations and diminishing the ecosystem services they provide. Additionally, greater complexity on oyster reefs is important for mitigating predation (Grabowski 2004), and reductions in oyster growth could minimize the refuge value of reef habitats.

To determine if predators alter oyster morphology in the field using natural predator densities, we performed a manipulative experiment using mud crabs Panopeus herbstii, Eastern oysters, and 2 additional common bivalves found on oyster reefs in the Southeastern USA: hard clams Mercenaria mercenaria and hooked mussels Ischadium recurvum. We elected to use mud crabs and associated bivalves as a model system for this study because mud crabs are common intermediate predators in oyster reef communities and can consume significant numbers of juvenile oysters and associated bivalves when not regulated by higher order consumers (Grabowski 2004, Grabowski \& Kimbro 2005). Our results suggest that in addition to consuming these bivalves, mud crab cues affect their growth but the effect is dependent upon bivalve species and size.

\section{MATERIALS AND METHODS}

This field experiment was conducted from June 15 to August 15, 2008 near the Skidaway Institute of Oceanography (SkIO) in Savannah, Georgia, USA, at Priest Landing and Cabbage Island (Fig. 1). We measured abiotic conditions in both sites each week during the study using Hydrolab Sondes. Both sites were similar in salinity measured on the practical salinity scale ( $33 \pm 0.15 \mathrm{SE}$ ) and water temperature $\left(32 \pm 0.6{ }^{\circ} \mathrm{C} \mathrm{SE}\right)$. These sites experience different hydrodynamic regimes as sites in the Wilmington River are mostly protected from waves, while sites on Cabbage Island are exposed to waves (see Smee et al. 2008, Ferner et al. 2009 for detailed hydrodynamic measurements).

We measured morphological changes in 3 of the most common bivalve species on oyster reefs: Eastern oysters, hard clams, and hooked mussels when in the presence of mud crab predators Panopeus herbstii. We used 2 size classes of bivalves and compared the changes in growth of soft tissue and shell as well as the susceptibility to mud crabs from each size. 


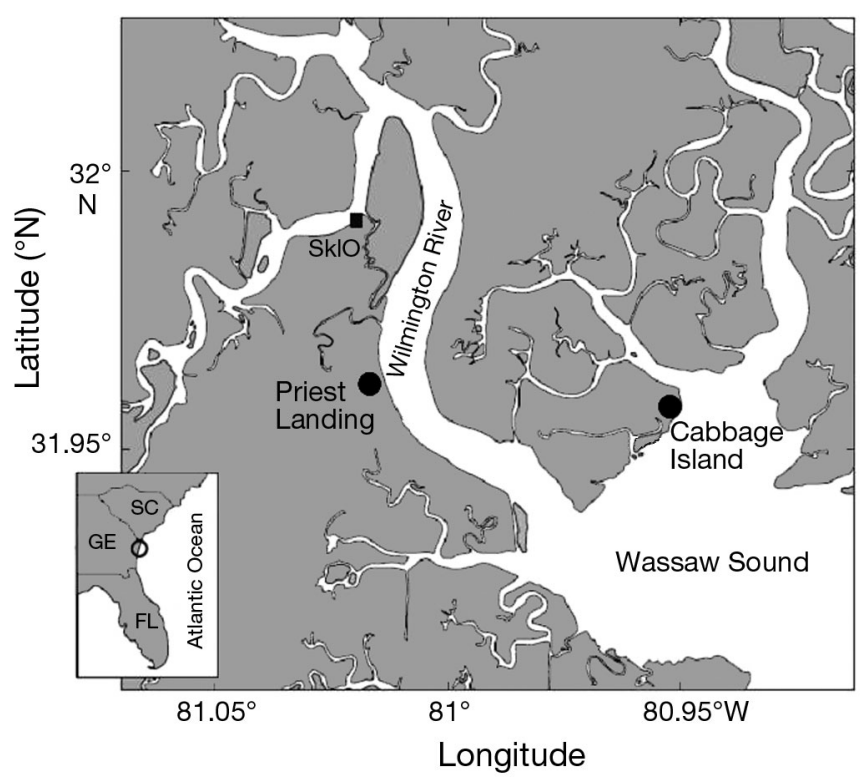

Fig. 1. Study area in Savannah, Georgia, USA, with field sites (-) and Skidaway Institute of Oceanography (SkIO,

Hatchery-reared Eastern oyster larvae Crassostrea virginica were purchased and settled onto grooved sections of polyvinyl chloride (PVC) pipe that were $10 \mathrm{~cm}$ in length. These juvenile oysters were allowed to grow for $2 \mathrm{wk}$ until they were $\sim 2 \mathrm{~mm}$ (shell height $[\mathrm{SH}])$, and then thinned so that 10 oysters were present on each piece of PVC. Larger juvenile oysters (10 to $15 \mathrm{~mm} \mathrm{SH}$ ) were collected from oyster shells placed into the field, which collected naturally settling individuals in the spring. Two size classes of hard clams, 5 to 10 and 10 to $15 \mathrm{~mm}$ measured from the umbo to outermost edge of the shell, were purchased from a commercial hatchery. Hooked mussels were collected from pilings near SkIO and were separated into size classes: small 5 to $10 \mathrm{~mm}$ and large 10 to $15 \mathrm{~mm}$. Both large and small bivalves used in this study are relatively small and can grow rapidly in warm conditions with abundant food (Ingle \& Dawson 1952). The larger classes however were less susceptible to crushing predators like crabs. The mud crabs used in this experiment were $P$. herbstii collected from oyster reefs adjacent to our field sites. Crabs used were 20 to $30 \mathrm{~mm}$ carapace width.

\section{Bivalve growth}

We wanted to insure that all organisms were growing during the experiment and that any differences noted in final tissue and shell weights between predator treatments would reflect changes in resource allocation and not starvation or a lack of new growth. To quantify growth on experimental bivalves, we measured initial and final wet weights of clams and mussels. Wet weights can be unreliable and highly variable, so we calculated a regression using final wet weight vs. final dry weight to verify that wet weights were reasonable estimates for dry weight and subsequent growth. Values of $\mathrm{r}^{2}$ were above 0.90 for all relationships, indicating that wet weights were appropriate measurements of respective growth among treatments. We did not measure initial weights of oysters as we were unable to remove them from their attachment points without injury. Changes in wet weights for clams and mussels were compared with $t$-tests for each size class (Sokal \& Rohlf 1995).

\section{Changes in bivalve mass after predator exposure}

Five of each size class (large and small) of oysters, clams, and mussels were securely placed in cages $(40 \times 20 \times 15 \mathrm{~cm})$ and these cages were deployed in pairs within oyster reefs at each study site. One member of the paired cages contained a single mud crab, while the other did not and served as a control. Mud crabs were contained within a $5.0 \mathrm{~cm}$ cylindrical cage within the larger cage so that the mud crabs could not contact or consume the bivalves. Ten pairs of cages were placed in each study site. Within pairs, individual cages were placed $\sim 1.0 \mathrm{~m}$ apart, at $\sim 0.5 \mathrm{~m}$ above the mean lower low water (MLLW) line, and pairs were placed $\sim 20 \mathrm{~m}$ apart. The cylindrical cages were also present in controls but did not contain mud crabs. Cages were checked weekly, at which time mud crabs were fed live, intact clams, and mussels and missing or dead crabs were replaced. Drift algae and sediment were also removed from cages during weekly inspections. Cages remained in the field for $45 \mathrm{~d}$, which was sufficient time to observe significant increases in growth of all species and size classes.

After $45 \mathrm{~d}$, the oysters, clams, and mussels were returned to the lab to quantify their final tissue and shell mass. We elected to use mass as a proxy for relative energy allocation in response to predators because individual bivalves, oysters in particular, exhibit great variation in size and shape, making measurements of shell length or width difficult to obtain. In preliminary studies, we noted that measurements of shell length and width were subject to significant measurement errors, which were avoided by measuring mass. Further, oysters are firmly attached to substrates and their growth patterns vary 
widely, which make measuring their shell thickness or width/length relationships growth difficult.

Bivalve tissue and shell mass were calculated after the $45 \mathrm{~d}$ field experiment, using the following protocol. First, all bivalves were placed into a conventional drying oven at $90^{\circ} \mathrm{C}$ for $2 \mathrm{~d}$ and the dry mass of each individual recorded. This provided a measure of shell and soft tissue weight combined. Then, all bivalves were transferred to a muffle furnace and baked for $2 \mathrm{~h}$ at $500^{\circ} \mathrm{C}$ to remove all soft tissue. Each bivalve was reweighed to obtain weights of the shell only (ash-free dry mass). The shell weight was subtracted from the dry mass to find the tissue mass.

Two-way ANOVAs were used to examine the growth differences between treatments for each size and type of organism, with site and predator treatment as fixed factors in the ANOVA model (Sokal \& Rohlf 1995). We did not compare tissue or shell weights among different species or sizes of bivalves due to inherent differences in shell thickness and growth rates between species and sizes. Site was not significant ( $p>0.2)$ nor was the interaction of site and treatment $(p>0.3)$. We therefore pooled data between sites and used $t$-tests to compare differences in final mass of tissue and shell for each bivalve size and species between mud crab treatments and controls (Sokal \& Rohlf 1995)

\section{Feeding assays}

We performed feeding assays to determine if smaller bivalves were more vulnerable to predation by mud crabs. In these experiments, we placed 1 small and 1 large bivalve in a 2.01 glass jar contain- ing aerated seawater, and we then measured the time needed for both bivalves to be eaten. Small and large size classes used were the same as those noted above. Time was measured as the number of $1 \mathrm{~h}$ periods elapsed before consumption. We covered the sides of the tanks with black paper to minimize visual distractions to the crabs. The assays were stopped after $24 \mathrm{~h}$ or when both bivalves were consumed. Sixteen assays were performed with clams and mussels. We elected not to use oysters for these experiments because we could not remove newly settled oysters from our PVC sticks without injuring them and felt that presenting oysters to predators settled onto a stick would not be a suitable comparison to a single oyster of a slightly larger size. We compared the time until the small vs. large clams or mussels were eaten separately using a nonparametric sign test (Sokal \& Rohlf 1995).

\section{RESULTS}

\section{Bivalve growth}

Wet weight was highly correlated with dry weight $\left(\mathrm{r}^{2}>0.90\right)$, indicating that wet weight was a reasonable approximation for final dry weight and overall growth. Mass increased for both size classes of each species during the experiment, but we did not find significant differences in growth between mud crab treatments and controls: (large clams: $F_{1,43}=0.88, \mathrm{p}=$ 0.37; small clams: $F_{1,13}=1.48, \mathrm{p}=0.14$; large mussels: $F_{1,21}=1.68, \mathrm{p}=0.10 ;$ small mussels $F_{1,31}=1.47, \mathrm{p}=$ 0.14 ; Figs. $2 \& 3$ ). Thus, differences in tissue and shell weights between predator treatments and controls

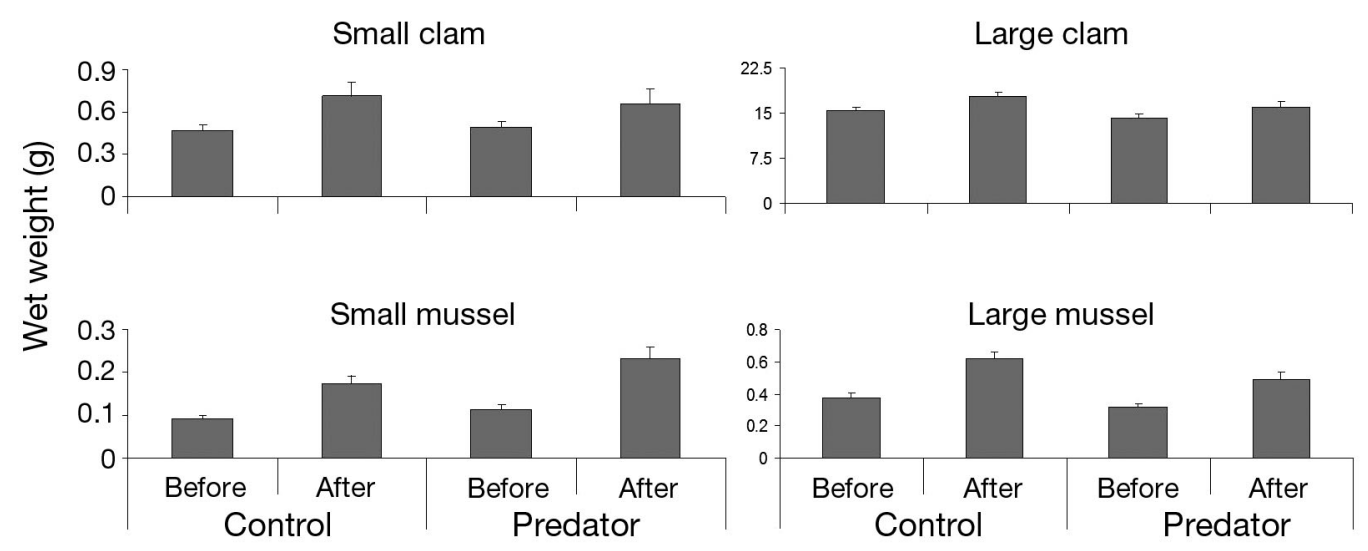

Fig. 2. Mercenaria mercenaria and Ischadium recurvum. Mean wet weight \pm SE of clams and mussels at the beginning and end of the experiment. All species and size classes grew during the experiment 


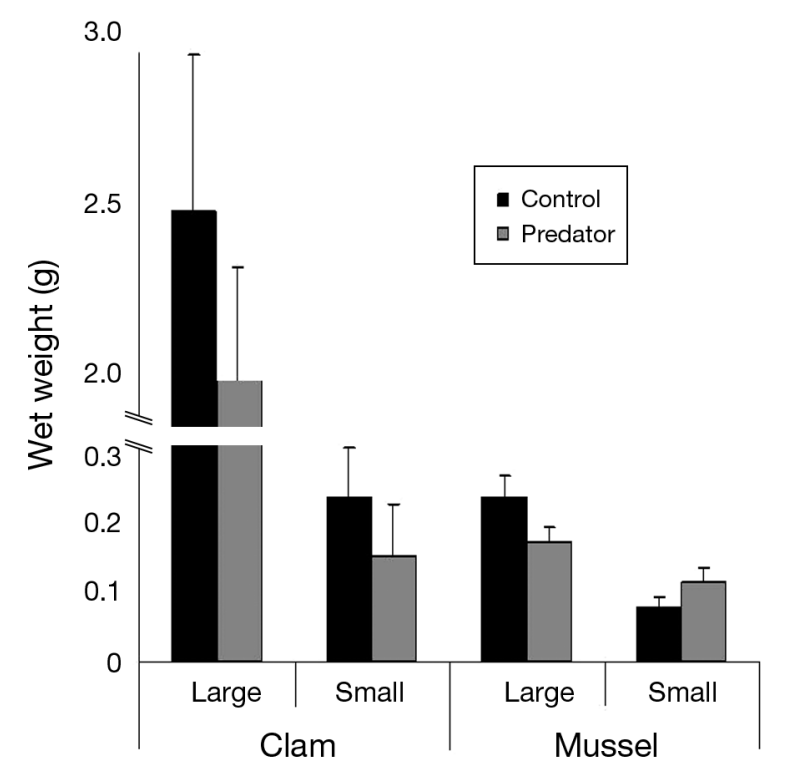

Fig. 3. Mercenaria mercenaria and Ischadium recurvum. Mean wet weight \pm SE gained during the experiment by species, size, and treatment. Significant differences were not found between treatments using $t$-tests
Fig. 4). We did not observe significant changes in shell mass between mud crab and control treatments for either small oysters $\left(F_{1,60}=0.36, \mathrm{p}=0.58\right)$ or small clams $\left(F_{1,46}=0.18, \mathrm{p}=0.67\right.$, Fig. 4$)$. There was not a significant difference in the tissue $\left(F_{1,56}=0.10, \mathrm{p}=0.75\right)$ mass for small mussels with and without mud crabs present. Unlike oysters and clams, small mussels produced more shell mass in response to mud crabs $\left(F_{1,56}=3.24, \mathrm{p}=0.07\right)$, which is significant at $\alpha=0.1$.

\section{Feeding assays}

Smaller clams and mussels were consumed significantly more quickly than larger individuals ( $\mathrm{p}<$ 0.05), indicating that smaller bivalves are more vulnerable to mud crabs. In 12 of the assays with clams, the larger clam was not consumed after $24 \mathrm{~h}$. In the 4 assays where the large clam was consumed, the mud crab ate the smaller clam first. In 8 of the mussel feeding assays, the smaller mussel was consumed first. In 4 assays, large and small mussels were consumed during the same $1 \mathrm{~h}$ period, and in the remaining 4 neither mussel was consumed. resulted from changes in allocation of resources rather than differences in growth rates among bivalve size classes.

\section{Changes in bivalve mass after predator exposure}

Tissue and shell weights were not statistically different between predator treatments for the larger size classes of oysters (tissue $F_{1,116}=0.25$, $\mathrm{p}=0.61$; shell $F_{1,116}=0.29, \mathrm{p}=0.58$ ). Large mussel tissue and shell growth was significantly less in mud crab treatments at $\alpha=0.1$ (tissue $F_{1,38}=$ 2.91, $\mathrm{p}=0.09$; shell $F_{1,38}=3.44, \mathrm{p}=$ 0.07, Fig. 4). Large clams grew significantly less shell in the presence of mud crabs but their soft tissue growth was not significantly different (tissue $F_{1,85}=0.27, \mathrm{p}=0.61$; shell $F_{1,85}=1.98$, $\mathrm{p}=0.02$ ). In contrast, mud crabs affected tissue mass but not shell mass in the smaller bivalves as tissue masses were significantly lower for small oysters $\left(F_{1,60}=13.34, \mathrm{p}<0.001\right)$ and small clams $\left(F_{1,46}=5.85, \mathrm{p}=0.02\right.$,
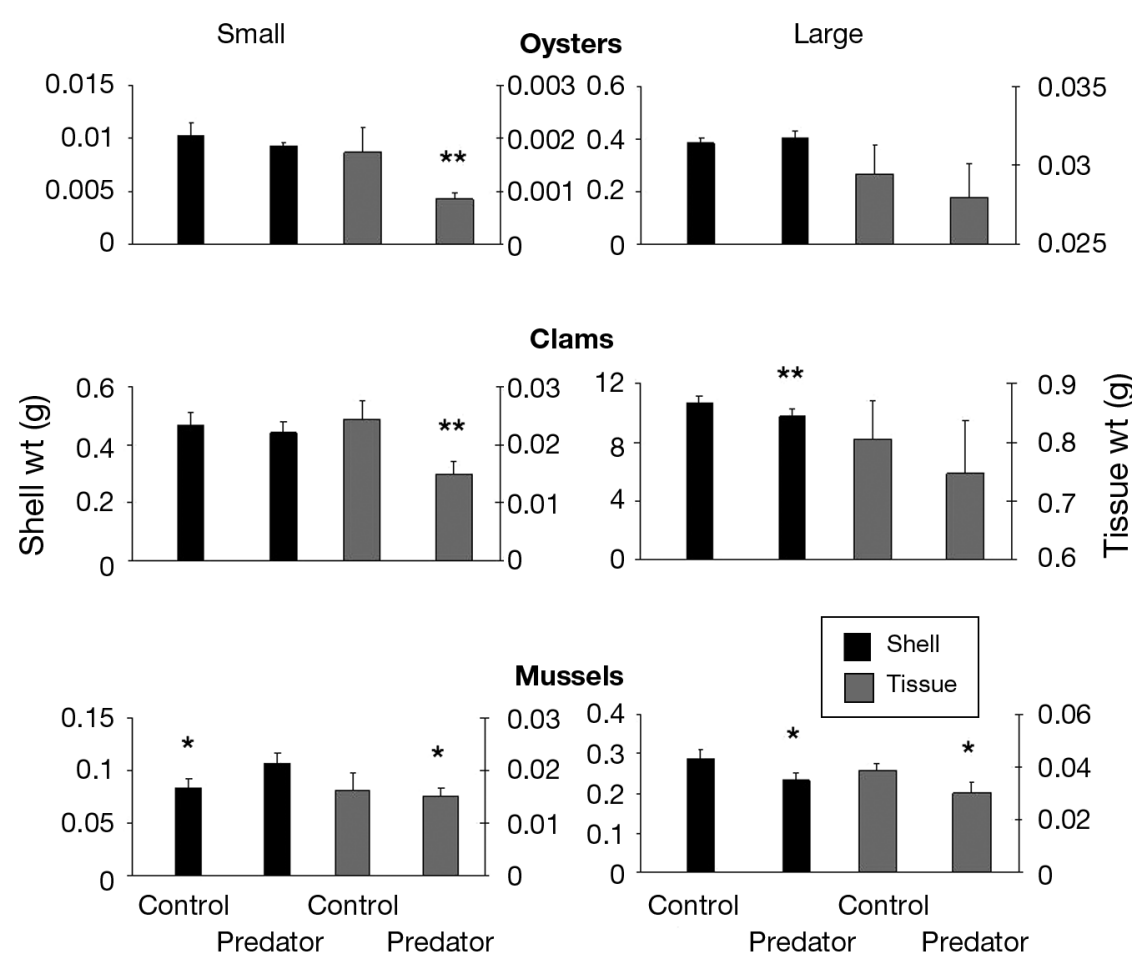

Fig. 4. Crassostrea virginica, Mercenaria mercenaria, and Ischadium recurvum. Mean change in shell and tissue weight \pm SE for large and small clams, oysters and mussels by control and predator treatment. Error bars: SE; significance: ${ }^{* *} p<0.05,{ }^{*} p<0.1$, based on a $t$-test 


\section{DISCUSSION}

Bivalves exhibit both behavioral and morphological defenses against predators, and our results suggest that size influences their predator avoidance responses. Prey size often affects vulnerability to predators and subsequent lethal predator effects in communities (Micheli 1995, Wong et al. 2010). By inducing avoidance responses in prey, predators may initiate trophic cascades that are similar in magnitude to those generated through direct prey consumption (Trussell et al. 2003, Werner \& Peacor 2003, Preisser et al. 2009). Our findings suggest that size may also affect if and how prey react to consumers and should be considered in determining the scales of nonlethal predator effects and the extent to which predators indirectly affect multiple trophic levels.

Bivalves can reduce predation risk through changes in behavior (Griffiths \& Richardson 2006, Smee \& Weissburg 2006, Naddafi et al. 2007, Flynn \& Smee 2010), morphology (Leonard et al. 1999, Newell et al. 2007, Lord \& Whitlatch 2012), or a combination of defensive strategies (Freeman 2007, Naddafi et al. 2007, Freeman et al. 2009). They may build a stronger shell as protection from crushing consumers like crabs (Micheli 1995, Leonard et al. 1999, Nakaoka 2000). Mussels exhibit additional morphological defenses against predators including producing extra byssal threads to more firmly attach themselves to the substrate (Cote 1995, Leonard et al. 1999, Shin et al. 2009) and/or grow thicker abductor muscles to discourage prying predators (Freeman 2007, Freeman et al. 2009). Some bivalves reduce predation risk by reducing their feeding rates to minimize release of cues that attract predators (Smee \& Weissburg 2006, Naddafi et al. 2007), while others burrow more deeply to escape from burrowing consumers (Griffiths \& Richardson 2006, Flynn \& Smee 2010).

Regardless of the mechanism used to reduce predation risk, the expression of defenses incurs costs such as reductions in growth and fecundity as resources are expended (Nakaoka 2000, Relyea 2002). Chronic stress alone can decrease growth rates (Edeline et al. 2010), which may extend the time bivalves are vulnerable to mud crabs and increase their mortality (Micheli 1995, Wong et al. 2010). Additional work is needed to more clearly link reductions in growth to specific predator avoidance responses in the species used in this study, as well as to establish long term effects on mortality, growth, and fecundity.
From our data it is clear that size can influence if and how prey respond to predators. In oysters, smaller individuals produced less soft tissue in response to crabs but larger individuals did not (Fig. 4). Laboratory studies have shown oysters to grow stronger shells in response to blue crabs (Newell et al. 2007) and oyster drills (Lord \& Whitlatch 2012), and the reduction in soft tissue growth may have occurred as smaller, more vulnerable, oysters allocated more energy to shell strengthening and less to tissue growth.

Mud crabs affected growth of both large and small clams, but did so in different ways. Smaller clams grew less soft tissue while larger individuals grew less shell mass. Hard clams react to crabs by reducing feeding time to minimize release of metabolites that attract predators and close their valves to protect siphons and soft tissues (Smee \& Weissburg 2006, Smee et al. 2008). In this study, growth reductions in clams may be explained by lost feeding time, but, the costs associated with predator avoidance manifested themselves in different ways based on size. Unlike mud crabs, knobbed whelks tend to forage on larger clams (>30 mm) (Peterson 1982), and larger clams grew less in response to whelks while the growth of smaller clams $(<30 \mathrm{~mm})$ that are not eaten by whelks were unaffected by their presence in the field (Nakaoka 2000). Thus, clams respond differently to mud crabs than knobbed whelks in a manner that seems adaptive based upon relative risk of each predator.

Small and large mussels also responded to mud crabs differently. Small mussels increased shell mass in predator treatments, which has been reported for other mussel species (Smith \& Jennings 2000, Cheung et al. 2004). Smaller mussels did not reduce soft tissue growth in predator treatments even though they grew a thicker shell. This may have occurred because mussels produce additional byssal threads in response to predators to make it more difficult for predators to dislodge and crush them (Cote 1995, Leonard et al. 1999, Fassler \& Kaiser 2008). Soft tissue mass included mass from byssal threads, and thus we were unable to determine if mussels were allocating soft tissue growth differently in predator treatments (Fig. 4). Unlike the smaller mussels, larger mussels grew less tissue and shell in predator treatments (Fig. 4).

Oysters and clams are commercially important species, and lowering their fecundity may have longterm economic and ecological consequences. Despite their importance as a commercial fishery and as a foundation species in estuaries, oyster populations 
are declining in many areas of the U.S. (Rothschild et al. 1994, Jackson et al. 2001, Kirby 2004). Our results, along with earlier studies (Grabowski \& Powers 2004, Grabowski et al. 2005), indicate the importance of maintaining sufficient populations of higher order predators to consume mud crabs and maintain topdown control, and alleviate both lethal and nonlethal effects propagating from mud crabs to juvenile oysters and other bivalves. Further, larger bivalves are mostly commonly targeted for harvesting, leaving the smaller individuals - which are more vulnerable to predators and more likely to alter growth patterns in response to predators - to replenish the population (Fenberg \& Roy 2008). Consideration of both lethal and nonlethal predator effects at multiple trophic levels should be incorporated into management plans of bivalve fisheries.

Acknowledgements. This research was supported by National Science Foundation (OCE-0648433) and the Texas Research Development Fund to D.L.S. The Skidaway Institute of Oceanography and the Texas A\&M University - Corpus Christi Center for Coastal Studies provided facilities that made the work possible. The field work would not have been possible without the help of N. Schoeppner, J. Hill, and M. Watts from Georgia Tech. The Marine Ecology Lab at Texas A \& M University-Corpus Christi, especially P. Torres and J. Sanchez, provided valuable lab assistance. We appreciated helpful comments from J. Grabowski. K. Withers, J. Hill, and 3 anonymous reviewers that greatly improved this submission.

\section{LITERATURE CITED}

Bourdeau PE (2010) Cue reliability, risk sensitivity and inducible morphological defense in a marine snail. Oecologia 162:987-994

> Caro AU, Castilla JC (2004) Predator-inducible defences and local intrapopulation variability of the intertidal mussel Semimytilus algosus in central Chile. Mar Ecol Prog Ser 276:115-123

Cheung SG, Lam S, Gao QF, Mak KK, Shin PKS (2004) Induced anti-predator responses of the green mussel, Perna viridis (L.), on exposure to the predatory gastropod, Thais clavigera Küster, and the swimming crab, Thalamita danae Stimpson. Mar Biol 144:675-684

Cote IM (1995) Effects of predatory crab effluent on byssus production in mussels. J Exp Mar Biol Ecol 188:233-241

Crowl TA, Covich AP (1990) Predator-induced life-history shifts in a freshwater snail. Science 247:949-951

$>$ Edeline E, Haugen TO, Weltzien FA, Claessen D, Winfield IJ, Stenseth NC, Vollestad LA (2010) Body downsizing caused by non-consumptive social stress severely depresses population growth rate. Proc R Soc Lond B Biol Sci 277:843-851

- Fassler SMM, Kaiser MJ (2008) Phylogenetically mediated anti-predator responses in bivalve molluscs. Mar Ecol Prog Ser 363:217-225

Fenberg PB, Roy K (2008) Ecological and evolutionary consequences of size-selective harvesting: How much do we know? Mol Ecol 17:209-220

Ferner MC, Smee DL, Weissburg MJ (2009) Habitat complexity alters lethal and non-lethal olfactory interactions between predators and prey. Mar Ecol Prog Ser 374: $13-22$

Ferrari MCO, Wisenden BD, Chivers DP (2010) Chemical ecology of predator-prey interactions in aquatic ecosystems: a review and prospectus. Can J Zool 88:698-724

> Flynn AM, Smee DL (2010) Behavioral plasticity of the softshell clam, Mya arenaria (L.), in the presence of predators increases survival in the field. J Exp Mar Biol Ecol 383:32-38

- Freeman AS (2007) Specificity of induced defenses in Mytilus edulis and asymmetrical predator deterrence. Mar Ecol Prog Ser 334:145-153

Freeman AS, Meszaros J, Byers JE (2009) Poor phenotypic integration of blue mussel inducible defenses in environments with multiple predators. Oikos 118:758-766

Grabowski JH (2004) Habitat complexity disrupts predatorprey interactions but not the trophic cascade on oyster reefs. Ecology 85:995-1004

> Grabowski JH, Kimbro DL (2005) Predator-avoidance behavior extends trophic cascades to refuge habitats. Ecology 86:1312-1319

Grabowski JH, Peterson CH (2007) Restoring oyster reefs to recover ecosystem services. In: Cuddington $\mathrm{K}$, Byers JE, Wilson WG, Hastings A (eds) Ecosystem engineers: concepts, theory and applications. Elsevier Academic Press, Amsterdam, p 281-298

Grabowski JH, Powers SP (2004) Habitat complexity mitigates trophic transfer on oyster reefs. Mar Ecol Prog Ser 277:291-295

> Grabowski JH, Hughes AR, Kimbro DL, Dolan MA (2005) How habitat setting influences restored oyster reef communities. Ecology 86:1926-1935

Griffiths CL, Richardson CA (2006) Chemically induced predator avoidance behavior in the burrowing bivalve, Macoma balthica. J Exp Mar Biol Ecol 331:91-98

Harvell CD (1990) The ecology and evolution of inducible defenses. Q Rev Biol 65:323-340

- Hay ME (2009) Marine chemical ecology: chemical signals and cues structure marine populations, communities, and ecosystems. Annu Rev Mar Sci 1:193-212

Ingle RM, Dawson CE Jr (1952) Growth of the American Oyster, Crassostrea virginica (Gmelin) in Florida Waters. Bull Mar Sci 2:393-404

Irlandi EA, Peterson CH (1991) Modification of animal habitat by large plants - mechanisms by which seagrasses influence clam growth. Oecologia 87:307-318

> Jackson JBC, Kirby MX, Berger WH, Bjorndal KA and others (2001) Historical overfishing and the recent collapse of coastal ecosystems. Science 293:629-637

Kats LB, Dill LM (1998) The scent of death: chemosensory assessment of predation risk by prey animals. Ecoscience 5:361-394

Kirby MX (2004) Fishing down the coast: historical expansion and collapse of oyster fisheries along continental margins. Proc Natl Acad Sci USA 101:13096-13099

Large SI, Smee DL (2010) Type and nature of cues used by Nucella lapillus to evaluate predation risk. J Exp Mar Biol Ecol 396:10-17

Leonard GH, Bertness MD, Yund PO (1999) Crab predation, waterborne cues, and inducible defenses in the blue mussel, Mytilus edulis. Ecology 80:1-14

Lively CM (1986) Competition, comparative life histories, 
and maintenance of shell dimorphism in a barnacle. Ecology 67:858-864

Lord JP, Whitlatch RB (2012) Inducible defenses in the eastern oyster Crassostrea virginica Gmelin in response to the presence of the predatory oyster drill Urosalpinx cinerea Say in Long Island Sound. Mar Biol 159: $1177-1182$

Micheli F (1995) Behavioral plasticity in prey-size selectivity of the blue crab Callinectes sapidus feeding on bivalve prey. J Anim Ecol 64:63-74

Naddafi R, Eklov P, Pettersson K (2007) Non-lethal predator effects on the feeding rate and prey selection of the exotic zebra mussel Dreissena polymorpha. Oikos 116: $1289-1298$

Nakaoka M (2000) Nonlethal effects of predators on prey populations: predator-mediated change in bivalve growth. Ecology 81:1031-1045

Newell R, Kennedy V, Shaw K (2007) Comparative vulnerability to predators, and induced defense responses, of eastern oysters Crassostrea virginica and non-native Crassostrea ariakensis oysters in Chesapeake Bay. Mar Biol 152:449-460

Peterson CH (1982) Clam predation by whelks (Busycon spp): experimental tests of the importance of prey size, prey density, and seagrass cover. Mar Biol 66:159-170

Peterson CH (1986) Quantitative allometry of gamete production by Mercenaria mercenaria into old age. Mar Ecol Prog Ser 29:93-97

Preisser EL, Bolnick DI, Grabowski JH (2009) Resource dynamics influence the strength of non-consumptive predator effects on prey. Ecol Lett 12:315-323

Relyea RA (2001) Morphological and behavioral plasticity of larval anurans in response to different predators. Ecology 82:523-540

Relyea RA (2002) Costs of phenotypic plasticity. Am Nat 159: 272-282

Rothschild BJ, Ault JS, Goulletquer P, Heral M (1994) Decline of the Chesapeake Bay oyster population: a century of habitat destruction and overfishing. Mar Ecol

Editorial responsibility: Kenneth Heck,

Dauphin Island, Alabama, USA
Prog Ser 111:29-39

Schoeppner NM, Relyea RA (2005) Damage, digestion, and defence: the roles of alarm cues and kairomones for inducing prey defenses. Ecol Lett 8:505-512

Schoeppner NM, Relyea RA (2008) Detecting small environmental differences: risk-response curves for predatorinduced behavior and morphology. Oecologia 154: 743-754

Shin PKS, Yang FY, Chiu MY, Cheung SG (2009) Cues from the predator crab Thalamita danae fed different prey can affect scope for growth in the prey mussel Perna viridis. Mar Freshw Behav Physiol 42:343-355

Smee DL, Weissburg MJ (2006) Clamming up: environmental forces diminish the perceptive ability of bivalve prey. Ecology 87:1587-1598

Smee DL, Ferner MC, Weissburg MJ (2008) Alteration of sensory abilities regulates the spatial scale of nonlethal predator effects. Oecologia 156:399-409

Smith LD, Jennings JA (2000) Induced defensive responses by the bivalve Mytilus edulis to predators with different attack modes. Mar Biol 136:461-469

Sokal R, Rohlf F (1995) Biometry: the principles and practice of statistics in biological research. WH Freeman, New York, NY

> Toscano BJ, Griffen BD (2012) Predatory crab size diversity and bivalve consumption in oyster reefs. Mar Ecol Prog Ser 445:65-71

Trussel GC, Ewanchuk PJ, Bertness MD (2003) Trait-mediated effects in rocky intertidal food chains: predator risk cues alter prey feeding rates. Ecology 84:629-640

Turner AM (2004) Non-lethal effects of predators on prey growth rates depend on prey density and nutrient additions. Oikos 104:561-569

Werner EE, Peacor SD (2003) A review of trait-mediated indirect interactions in ecological communities. Ecology 84:1083-1100

Wong MC, Peterson CH, Kay J (2010) Prey size selection and bottom type influence multiple predator effects in a crab-bivalve system. Mar Ecol Prog Ser 409:143-156

Submitted: October 29, 2011; Accepted: May 7, 2012

Proofs received from author(s): July 31, 2012 